\title{
Cordulegaster bidentata Selys, 1843 in fragmented landscape of the Wielickie Foothills: reassesement of the northern limit of species range in the Western Carpathians
}

\author{
Rafał BOBREK \\ Polish Society for the Protection of Birds, Odroważa 24,05-270 Marki, Poland; e-mail: rafal.bobrek@gmail.com; \\ https://orcid.org/0000-0002-8304-5583
}

\begin{abstract}
In 2018-2019, the occurrence of Cordulegaster bidentata Selys, 1843 in the Wielickie Foothills, located between the Beskidy mountain ranges (in the south) and the Vistula river valley (in the north) was investigated. It was examined whether $C$. bidentata inhabits fragmented landscape, with forest patches of various sizes. Larvae of this dragonfly were searched in the forest streams, the bottom of which was visually scanned using binoculars. The presence of 49 larvae was confirmed on 17 stream sections out of $53(32 \%)$. They were recorded in almost the entire geographical extent of the study area, from the southernmost to the northernmost forest patches. The neighboring occupied streams were separated by a maximum of $3.7 \mathrm{~km}$, and breeding sites were found in forest patches of an area of $75-1280 \mathrm{ha}$. It was confirmed that $C$. bidentata occurs up to the orographic edge of the Western Carpathians. Its range is continuous between the northern edge of the Beskidy Mountains and the Vistula valley. New data shift the northern range limit of C. bidentata in the Western Carpathians by nearly $20 \mathrm{~km}$. The field method used proved to be efficient in assessing the distribution of larvae in large areas, with relatively little field effort. Its wider use would allow a more complete recognition of distribution of $C$. bidentata in the Carpathian Foothills.
\end{abstract}

Key words: dragonflies Odonata, Cordulegastridae, distribution, habitat patches, headwaters, mountain stream, Carpathians

\section{INTRODUCTION}

Cordulegaster bidentata Selys, 1843 (Odonata: Cordulegastridae) is an endemic dragonfly species in Europe, inhabiting uplands and low to medium mountain ranges of the western, central, southern and south-eastern part of the continent. Its range extends from the Pyrenees in the west to the Carpathians and the western Black Sea coast in the east and from the German Weser Upland in the north to Sicily and the northern part of the Peloponnese peninsula in the southern Europe (Fig. 1; Boudot 2001, 2010, Holuša 2009, IUCN 2009, Kalkman et al. 2010). The vertical range of this species extends between 100 and $2100 \mathrm{~m}$ asl (Boudot 2010). C. bidentata usually breeds in small, mid-forest headwater streams with clean water as well as in springs and seepage waters (Heidemann \& Seidenbusch 1993, Holuša 2009, Boudot \& Holuša 2015). It is considered a near-threatened (NT) species, and the population trend of this dragonfly in its entire range is assessed as decreasing (Boudot 2010, Kalkman et al. 2010).

In Poland, C. bidentata is a mountain species, distributed mainly in the Carpathians, with isolated, disjunctive fragments of range - including the Sudetes and the Świętokrzyskie Mountains - reaching further north (Fig. 2; Borkowski 1999, Bernard et al. 2009, Smolis et al. 2012). Currently, it is known in Poland from about 100 sites (Kłonowska-Olejnik \& Buczyński 2014), and its national population is not considered endangered or decreasing (Bernard et al. 2009). In the mountainous areas of the Carpathians, it is a moderately widespread, and in eastern part in suitable habitats - even a widespread species (Bernard et al. 2009, Gołąb et al. 2010, Kłonowska-Olejnik \& Buczyński 2014). However, the course of the northern limit of its Carpathian range is poorly studied. According to Bernard et al. (2009), the range does not include a significant part of the 
Carpathian Foothills (with the exception of the most eastern ones), and in the western part it reaches approximately to the northern borders of the Beskidy mountain ranges (Fig. 2). On the other hand, data of Kłonowska-Olejnik \& Buczyński (2014), from a single location in the Wiśnickie Foothills, indicate that $C$. bidentata reaches much further north, deeply into the region of western foothills.

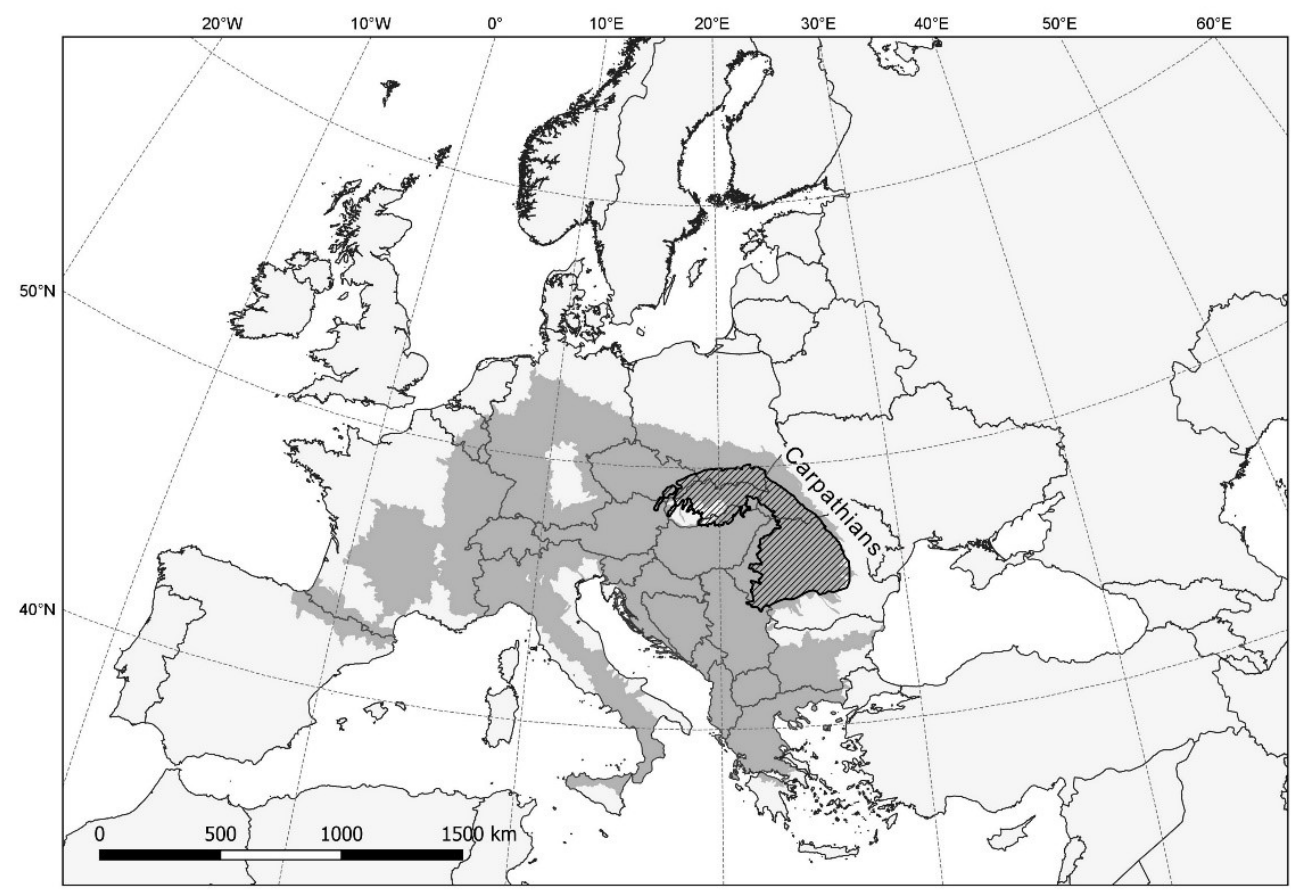

Fig. 1. Global range of Cordulegaster bidentata (dark grey), according to IUCN (2009).

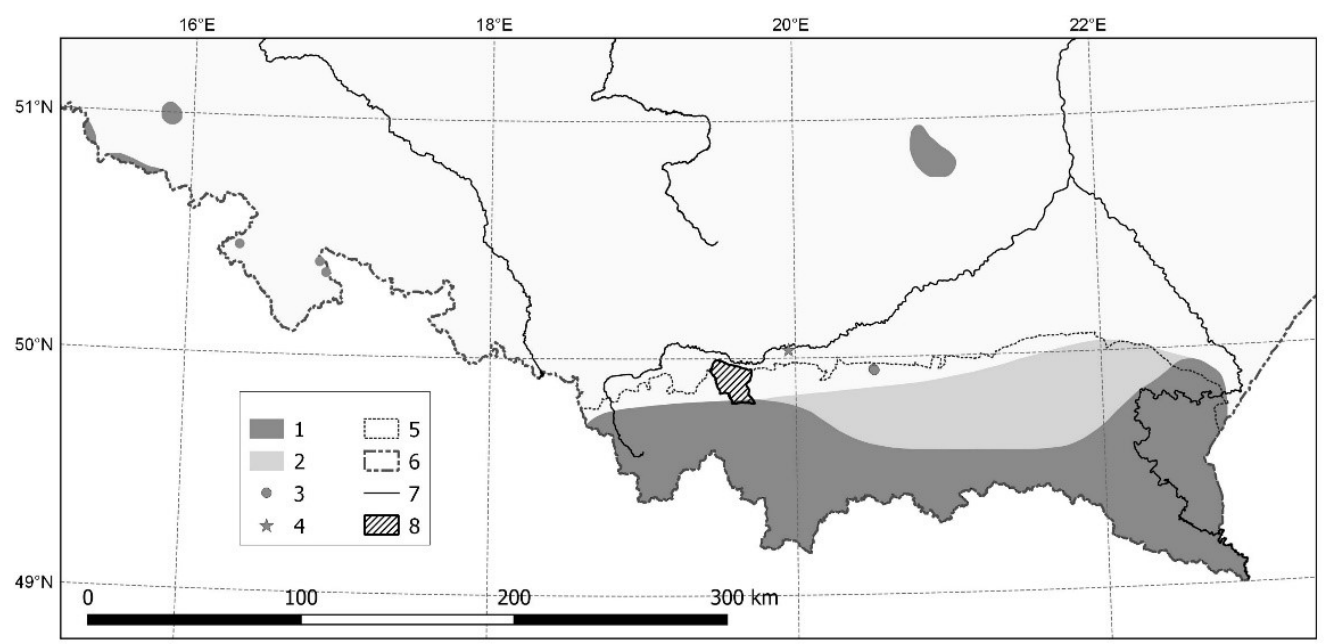

Fig. 2. Distribution of Cordulegaster bidentata in Poland. 1 - known range, 2 - potential range (according to Bernard et al. 2009, Smolis et al. 2012), 3 - disjuntive site in the Wiśnickie Foothills (Kłonowska-Olejnik \& Buczyński 2014), 4 past record of single imago from Kraków (Prüffer 1920), 5 - northern border of the Carpathians, 6 - state border, 7 main rivers, 8 - study area. 
Due to the uncertain course of the northern limit of species range in the Carpathian Foothills, and given the large area of this region, an attempt was made to assess this range limit in its selected part, the Wielickie Foothills. It is a region stretching between the known range of $C$. bidentata (i. e. the Beskidy Mountains; in the south) to the Vistula river valley (in the north), which marks here the northern border of the Carpathian mountain range (Fig. 2). A study of the species distribution in such a region should reveal how far north its range extends in the Carpathians. This area, compared to more mountainous regions of the Carpathians, is characterized by less forest cover and much greater fragmentation of forest patches, covering the hills cut by deep valleys of submontane streams (Kondracki 2013). So at the same time it was checked whether $C$. bidentata inhabits areas of the Carpathian Foothills with fragmented structure of forest landscape, in which islands of forest patches of different size are separated by non-forest habitats - agriculture land and villages.

\section{STUDY AREA, MATERIAL AND METHODS}

The study was conducted on the northern edge of the Western Carpathians, in the Wielickie Foothills, sloping via a distinct step to the north, towards the valley of the Vistula river (Figs 1 $\& 2$ ). The western part of the Wielickie Foothills (within the borders proposed by Solon et al. 2018) was chosen as the research area, located approximately between the valleys of the Skawa river in the west and Cedron river in the east. This area, covering $260.8 \mathrm{~km}^{2}$, is made of flysch deposits, covered by Pleistocene clays and gravels. It is predominantly agricultural, densely populated region, with small patches of mixed forests (up to $13 \mathrm{~km}^{2}$ ) preserved mainly on the hilltops, covering a total of $22 \%$ of the area (Margielewski et al. 2008, Kondracki 2013). The hills of this part of the Wielickie Foothills reach altitudes of 300-400 m a.s.l., and only in the southeastern part they exceed $500 \mathrm{~m}$ asl. In the forest-covered, highest parts of the hills numerous small watercourses begin, covering the area with a dense network of streams and rivers (Fig. 3). The climate of Wielickie Foothills is described as moderately warm, with annual precipitation in the range of 700-900 $\mathrm{mm}$ (Margielewski et al. 2008). The average annual air temperature is close to $9^{\circ} \mathrm{C}$, and the annual amplitude is around $21^{\circ} \mathrm{C}$. The average monthly minimum temperature in January reaches almost $-5^{\circ} \mathrm{C}$, and the maximum in August exceeds $23^{\circ} \mathrm{C}$. On average, there are 37 frost days per year (with a maximum temperature $\leq 0{ }^{\circ} \mathrm{C}$ ) (Limanówka 2008). The snow cover period lasts from mid-November to the end of March, but the number of days with snow cover is on average 62 per year (Pełech 2012).

The selected area was examined for the presence and distribution of $C$. bidentata larvae in 2018-2019. In the period between 12 May and 12 Oct, 21 field visits were carried out, with the highest intensity (9 visits) in August (Appendix 1). At least one stream was examined in each major forest patch. Initial, headwater sections of apparently fishless streams were selected, including those without continuous water flow, with a width not exceeding 3 meters. In total, 53 sections of total length of $21.5 \mathrm{~km}$, located on 47 streams, were searched (Appendix 1, Fig. 3). Individual sections differed in length, from 83 to $1137 \mathrm{~m}$, having on average $405.1 \mathrm{~m}$ (SD = $264.9 \mathrm{~m}$ ). The visual examination consisted of searching for $C$. bidentata larvae in the stream pools with a weak current, often forming up- and downstream from tree logs and boulders. The bottom of such pools was visually scanned, with the naked eye and with the use of $10 \times 42$ binoculars, with a short minimum focusing distance. Pools of such streams are small-area habitats, which is why the adopted method allowed to search the section in a relatively short time. Despite the fact that the larvae of this species tend to bury themselves in bottom sediments of the stream (Heidemann \& Seidenbusch 1993), the use of research methods involving disturbance of the watercourse bottom (like kick sampling, sieving or sweep-net sampling; Stark et al. 2001, Kłonowska-Olejnik \& Buczyński 2014) was completely abandoned, due to the 
sensitivity of local microhabitats. The search for adults and exuviae, recommended by some authors in combination with larvae searching (Tamm 2018), has proved ineffective in current research, as most of the field visits were carried out after the time of emergence and flight period of adult $C$. bidentata, which take place mostly between May and August (Liebelt et al. 2011, Tamm 2012). Larvae sampling was also chosen since it directly confirms species reproduction in a given place and its effectiveness, unlike the search for adults (Tamm 2012), is not related to the occurrence of sunny weather. Because the aim was to confirm the presence of the species on each stream section, not all pools were searched, but only those with the most suitable habitat. Stretches where the bottom of the stream was impossible to inspect visually due to the terrain conditions were avoided. At least several dozen pools were searched on each selected stream section.

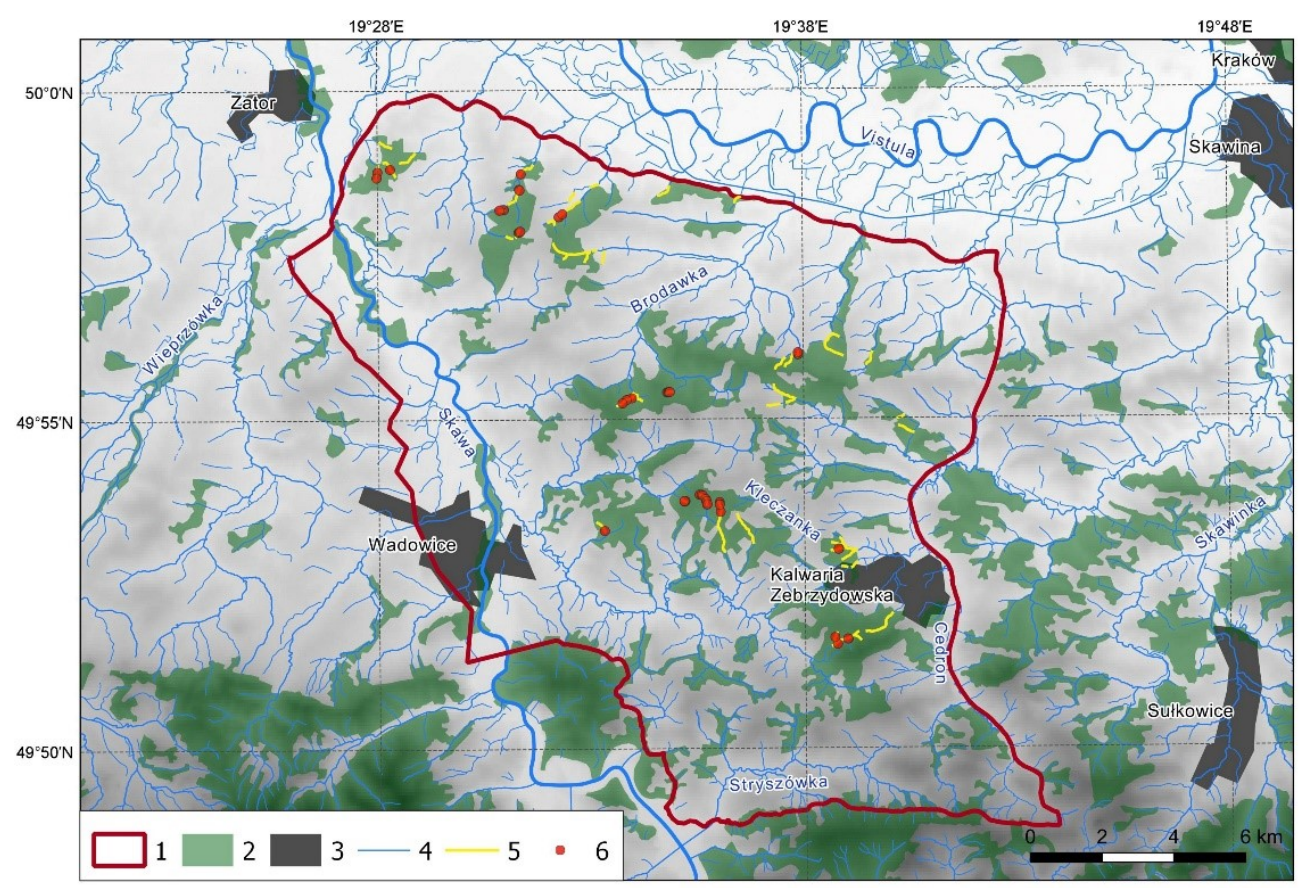

Fig. 3. Map of the study area and discovered sites of Cordulegaster bidentata. 1 - study area, 2 - forests, 3 - cities, 4 watercourses, 5 - searched stream sections, 6 - localities of C. bidentata larvae.

Each recorded larva was removed from the water and measured with a ruler (total length, to the nearest $1 \mathrm{~mm}$ ). Then the species was identified, focusing in particular on distinguishing $C$. bidentata from the related C. boltonii (Donovan, 1807), based on the absence of lateral spines on the VIII and IX segment of the abdomen (Heidemann \& Seidenbusch 1993). A 10× magnifying glass was used to support this. This feature is best seen in large larvae, which is why, after Kłonowska-Olejnik \& Buczyński (2014), it was assumed that larvae measuring at least 30 $\mathrm{mm}$ will be identified to the species level. Such individuals were also sexed, based on whether they had or lacked an ovipositor (Heidemann \& Seidenbusch 1993). Identification of smaller larvae was carried out only to the genus level. All larvae were released at the place of initial finding. A description of the habitat was made at each recorded C. bidentata site. The depth of water at which the larva was found and the maximum depth of the pool, as well as the width of the stream bed and its part filled with water were measured. The three-grade scale was used to 
evaluate the water flow velocity (weak, intermediate, strong) at the location of the larvae and the level of shading (low, intermediate, high) of the stream pool. The approximate pool area (in $\mathrm{m}^{2}$ ), the characteristics of the bottom forming material (rock/stones, gravel, sand, clay; following Bis \& Mikulec 2013), and the presence of silt as well as the amount of detritus were visually evaluated. The general forest type (deciduous, coniferous or mixed) and the dominant tree species in the stand were visually assessed, within the sight range from each larval site. When visible, the presence of potential predators in the stream pool was registered. Due to the spatial autocorrelation of sites located within the same stream, the values were calculated as weighted means. The inverse of the number of sites located on a given stream was used as a weight. In order to assess the degree of spatial isolation of inhabited streams, the distance between the closest sites located on two streams nearest to each other was measured.

\section{RESULTS}

In 2018-2019, the presence of $C$. bidentata larvae was confirmed on 17 sections of 16 streams located in the western part of the Wielickie Foothills. This mean a 32\% share of sections and a $34 \%$ share of streams occupied by this species among all studied. Between $20 \mathrm{Jul}$ and 12 Oct, a total of 49 larvae of the species measuring $\geq 30 \mathrm{~mm}$ were found at 41 sites (Table 1). In addition, 15 larvae of Cordulegaster sp., 18-29 mm long, were found on the same streams sections, which due to their small size were not identified to the species level. Of the 49 identified larvae, 23 were males and 26 were females, so the sex ratio (males : females) was 1: 1.13. The largest female measured $40 \mathrm{~mm}$, and the largest male $-38 \mathrm{~mm}$. The distribution of sites where

C. bidentata larvae were found is presented in Fig. 3 .

Larvae were found in almost the entire meridian extent of the study area, from $49^{\circ} 51^{\prime}$ to $49^{\circ} 58^{\prime} \mathrm{N}$. The sites were recorded even in the northernmost forest complexes, located on the northwestern edge of the study area, sloping towards the Vistula valley (Fig. 3). The nearest sites located on two neighbouring occupied streams were 346-3720 m away, on average 1027.5 $(\mathrm{SD}=951.7) \mathrm{m}$. In fragmented landscape of the study area, this species was recorded in streams located in forest complexes with an area of 75-1280 ha. The sites of C. bidentata were located within the narrow valleys of small streams, on their initial, upper courses, close to springs. The habitat characteristics of each of the locations are presented in Table 2 . Of the 41 sites, $44 \%$ were located in deciduous forest, $29 \%$ in mixed forest and $27 \%$ in coniferous forest. In the forest stand, most frequently beech Fagus sylvatica L. (54\%) or common fir Abies alba Mill. (41\%) was the dominant species, and only rarely (5\%) another species dominated. Larvae were found at an altitude of $274-411 \mathrm{~m}$ a.s.l., on average $335.6 \mathrm{~m}(\mathrm{SD}=41.4)$ a.s.l., in streams with a riverbed width of $60-260 \mathrm{~cm}$, on average $136.6 \mathrm{~cm}(\mathrm{SD}=50.7)$ and a water table width of $20-170 \mathrm{~cm}$, on average $75.4 \mathrm{~cm}(\mathrm{SD}=36.8)$.

The longitudinal structure of most streams was characterized by alternating occurrence of deeper (pools) and shallower (riffles) fragments. C. bidentata larvae strongly preferred the former, as $93 \%$ of larvae sites were located within them. The occupied stream pools had an area of $0.2-6.0 \mathrm{~m}^{2}$, on average $1.6 \mathrm{~m}^{2}(\mathrm{SD}=1.6)$ and a maximum depth of $2-36 \mathrm{~cm}$, on average 11.8 $\mathrm{cm}(\mathrm{SD}=8.6)$. The larvae $(\mathrm{n}=49)$ usually occupied slightly shallower parts of pools, with a depth of $1.5-30 \mathrm{~cm}$, on average $7.3 \mathrm{~cm}(\mathrm{SD}=6.9)$. The bottom of streams in C. bidentata sites $(\mathrm{n}=41)$ was most often made of gravel (71\% of sites), then clay $(51 \%)$ or sand $(37 \%)$, and least often of large stones or solid rock $(22 \%)$. In addition, in $88 \%$ of the sites, the bottom substrate was covered partially (44\%) or almost completely (44\%) with a layer of silt, up to $5 \mathrm{~cm}$ thick. The amount of detritus (twigs, leaves, pieces of bark, etc.) in the stream pool seemed to be of no significance to $C$. bidentata larvae, as the sites were similarly often characterized by small (37\%), large (34\%) and medium (29\%) amount of bottom debris. The larvae were observed on the 
surface of the stream bottom - most of them were covered with a thin layer of sediment and therefore well camouflaged, but they were not buried in it. They occupied mostly places with medium strong current (54\% of sites), less often weak (29\%) or strong (17\%). Almost the same proportion of sites was shaded (49\%) as exposed to direct sunlight $(51 \%)$, but none of the sites was in full, deep shade. Stream pools were usually free from predators, only in two cases large predatory invertebrates were registered. They were the Aeshna cyanea (Muller, 1764) larva and the imago of Nepa cinerea L., 1758, but both of them were smaller than co-occurring $C$. bidentata larvae.

Table 1. The sites of Cordulegaster bidentata larvae found in streams of the Wielickie Foothills, their geographical coordinates $(\mathrm{X}, \mathrm{Y})$ and the number of larvae recorded at each site.

\begin{tabular}{|c|c|c|c|c|c|}
\hline Site ID & Section ID & Stream ID & $\mathrm{X}\left({ }^{\circ} \mathrm{E}\right)$ & $\mathrm{Y}\left({ }^{\circ} \mathrm{N}\right)$ & No. of larvae \\
\hline 1 & 4 & 3 & 19.648320 & 49.879732 & 1 \\
\hline 2 & 7 & 6 & 19.602097 & 49.891602 & 1 \\
\hline 3 & 7 & 6 & 19.602463 & 49.889154 & 2 \\
\hline 4 & 8 & 7 & 19.557460 & 49.884581 & 1 \\
\hline 5 & 4 & 3 & 19.648105 & 49.879646 & 1 \\
\hline 6 & 7 & 6 & 19.602117 & 49.891097 & 1 \\
\hline 7 & 7 & 6 & 19.602112 & 49.890983 & 1 \\
\hline 8 & 18 & 15 & 19.597190 & 49.891039 & 1 \\
\hline 9 & 18 & 15 & 19.595093 & 49.893460 & 1 \\
\hline 10 & 18 & 15 & 19.595566 & 49.893285 & 1 \\
\hline 11 & 18 & 15 & 19.596663 & 49.892441 & 1 \\
\hline 12 & 18 & 15 & 19.596962 & 49.891800 & 1 \\
\hline 13 & 18 & 15 & 19.597073 & 49.891877 & 1 \\
\hline 14 & 18 & 15 & 19.597340 & 49.891096 & 1 \\
\hline 15 & 19 & 17 & 19.588832 & 49.891935 & 1 \\
\hline 16 & 20 & 18 & 19.540371 & 49.963201 & 2 \\
\hline 17 & 24 & 21 & 19.524969 & 49.970168 & 1 \\
\hline 18 & 24 & 21 & 19.525237 & 49.969955 & 1 \\
\hline 19 & 27 & 21 & 19.525757 & 49.974037 & 1 \\
\hline 20 & 29 & 25 & 19.519090 & 49.965111 & 1 \\
\hline 21 & 29 & 25 & 19.518975 & 49.965074 & 1 \\
\hline 22 & 29 & 25 & 19.517998 & 49.965064 & 1 \\
\hline 23 & 29 & 25 & 19.517357 & 49.964941 & 3 \\
\hline 24 & 31 & 26 & 19.524773 & 49.959397 & 1 \\
\hline 25 & 31 & 26 & 19.525171 & 49.959444 & 1 \\
\hline 26 & 31 & 26 & 19.525390 & 49.959653 & 2 \\
\hline 27 & 32 & 27 & 19.581966 & 49.919171 & 1 \\
\hline 28 & 32 & 27 & 19.582411 & 49.919167 & 1 \\
\hline 29 & 32 & 27 & 19.582735 & 49.919236 & 2 \\
\hline 30 & 32 & 27 & 19.583062 & 49.919280 & 2 \\
\hline 31 & 34 & 30 & 19.568318 & 49.917755 & 1 \\
\hline 32 & 34 & 30 & 19.566254 & 49.917317 & 1 \\
\hline 33 & 34 & 30 & 19.564700 & 49.916489 & 2 \\
\hline 34 & 37 & 33 & 19.470038 & 49.974652 & 1 \\
\hline 35 & 37 & 33 & 19.469694 & 49.973181 & 1 \\
\hline 36 & 38 & 34 & 19.474963 & 49.975329 & 1 \\
\hline 37 & 46 & 41 & 19.651680 & 49.857193 & 1 \\
\hline 38 & 46 & 41 & 19.651452 & 49.857176 & 1 \\
\hline 39 & 48 & 44 & 19.646538 & 49.857601 & 1 \\
\hline 40 & 51 & 47 & 19.632900 & 49.928443 & 1 \\
\hline 41 & 51 & 47 & 19.632872 & 49.928969 & 1 \\
\hline
\end{tabular}


Table 2. Habitat characteristics of 41 sites of Cordulegaster bidentata larvae in streams of the Wielickie Foothills. In the third column, the value for each larvae was given, according to their number in Table 1 for a given site. nd - no data, na - not applicable (measurement was not possible, e.g. the pool area, when the larva was recorded outside the stream pool).

\begin{tabular}{|c|c|c|c|c|c|c|c|c|c|c|c|c|c|}
\hline $\begin{array}{l}\text { Site } \\
\text { ID }\end{array}$ & $\begin{array}{l}\text { Altitude } \\
\text { [m a.s.l] }\end{array}$ & $\begin{array}{l}\text { Larvae water } \\
\text { depth }[\mathrm{cm}]\end{array}$ & $\begin{array}{l}\text { Max water } \\
\text { depth [cm] }\end{array}$ & $\begin{array}{l}\text { Water table } \\
\text { width }[\mathrm{cm}]\end{array}$ & $\begin{array}{l}\text { Stream bed } \\
\text { width [cm] }\end{array}$ & $\begin{array}{l}\text { Pool } \\
\text { area } \\
{\left[\mathrm{m}^{2}\right]}\end{array}$ & $\begin{array}{l}\text { Water flow } \\
\text { velocity }\end{array}$ & Shading & Forest type & $\begin{array}{l}\text { Dominant } \\
\text { tree } \\
\text { species }\end{array}$ & Bottom substrate & Silt cover & $\begin{array}{l}\text { Amount of } \\
\text { bottom } \\
\text { debris }\end{array}$ \\
\hline 1 & 2 & 3 & 4 & 5 & 6 & 7 & 8 & 9 & 10 & 11 & 12 & 13 & 14 \\
\hline 1 & 314 & 3 & 7 & 40 & 170 & nd & intermediate & low & coniferous & fir & gravel & no & small \\
\hline 2 & 358 & 8 & 13 & 80 & 170 & nd & weak & low & mixed & no & gravel & partial & small \\
\hline 3 & 344 & $21 / 23$ & 33 & 150 & 160 & 6.0 & weak & intermediate & coniferous & fir & clay & complete & small \\
\hline 4 & 305 & 3.5 & 14 & 90 & 110 & nd & intermediate & low & coniferous & fir & sand/gravel/clay & no & small \\
\hline 5 & 314 & 5 & 7 & 70 & 160 & nd & intermediate & low & coniferous & fir & stones/gravel/clay & partial & small \\
\hline 6 & 356 & 19 & 30 & 170 & 210 & nd & intermediate & low & coniferous & fir & sand/gravel/clay & complete & medium \\
\hline 7 & 349 & 9 & 12 & 130 & 170 & nd & weak & intermediate & coniferous & fir & clay/gravel & partial & medium \\
\hline 8 & 369 & 9 & 13 & 120 & 180 & nd & intermediate & intermediate & coniferous & fir & sand & partial & large \\
\hline 9 & 385 & 15 & 23 & 90 & 110 & nd & intermediate & intermediate & coniferous & fir & gravel & complete & large \\
\hline 10 & 380 & 7 & 8 & 40 & 100 & nd & intermediate & intermediate & mixed & fir & sand/gravel & partial & medium \\
\hline 11 & 377 & 7 & 8 & 45 & 160 & 0.2 & intermediate & intermediate & mixed & beech & sand/gravel & partial & large \\
\hline 12 & 372 & 2 & 2 & 65 & 80 & 0.2 & weak & low & mixed & beech & sand & complete & medium \\
\hline 13 & 370 & 13 & 17 & 70 & 130 & 0.7 & intermediate & low & mixed & beech & sand/gravel & partial & medium \\
\hline 14 & 368 & 23 & 26 & 160 & 170 & 1.6 & intermediate & intermediate & mixed & beech & sand/gravel & partial & large \\
\hline 15 & 380 & 2 & 9 & 80 & 100 & 0.5 & weak & low & mixed & beech & sand/gravel & partial & large \\
\hline 16 & 291 & $18 / 18$ & 24 & 110 & 180 & 2.0 & weak & intermediate & deciduous & beech & stones/gravel & complete & small \\
\hline 17 & 283 & 5 & 11 & 55 & 250 & 2.0 & intermediate & low & deciduous & beech & clay & complete & small \\
\hline 18 & 282 & 6 & 19 & 85 & 170 & 1.6 & intermediate & low & deciduous & beech & clay & complete & small \\
\hline 19 & 274 & 6 & 14 & 100 & 260 & 2.0 & weak & intermediate & deciduous & sycamore & rock/sand/gravel & complete & small \\
\hline 20 & 311 & 2 & 3 & 40 & 80 & 0.4 & intermediate & intermediate & deciduous & beech & gravel & complete & large \\
\hline 21 & 310 & 2 & 3 & 20 & 130 & na & intermediate & low & deciduous & beech & sand & no & small \\
\hline 22 & 307 & 2 & 6 & 50 & 150 & 2.0 & weak & intermediate & deciduous & beech & clay & complete & large \\
\hline 23 & 306 & $2 / 2 / 9$ & 9 & 30 & 170 & 0.4 & intermediate & low & deciduous & beech & stones/clay/gravel & partial & large \\
\hline 24 & 327 & 4 & 12 & 70 & 120 & 0.5 & intermediate & low & deciduous & beech & clay/sand & complete & medium \\
\hline 25 & 334 & 4 & 5 & 30 & 110 & 0.2 & intermediate & low & deciduous & beech & gravel/sand & partial & small \\
\hline
\end{tabular}


Continuation of the Table 2

\begin{tabular}{|c|c|c|c|c|c|c|c|c|c|c|c|c|c|}
\hline 1 & 2 & 3 & 4 & 5 & 6 & 7 & 8 & 9 & 10 & 11 & 12 & 13 & 14 \\
\hline 26 & 339 & $4 / 2$ & 12 & 60 & 110 & 0.6 & intermediate & intermediate & deciduous & beech & clay & complete & small \\
\hline 27 & 367 & 5 & 9 & 50 & 70 & 0.5 & strong & intermediate & deciduous & beech & clay/gravel & complete & small \\
\hline 28 & 367 & 3 & 3 & 50 & 160 & 0.2 & strong & intermediate & deciduous & beech & clay/gravel & partial & medium \\
\hline 29 & 367 & $1.5 / 2$ & 4 & 60 & 120 & 0.9 & strong & intermediate & deciduous & beech & clay & complete & large \\
\hline 30 & 362 & $2 / 3$ & 4 & 50 & 200 & 1.0 & strong & low & deciduous & beech & stones/gravel & partial & small \\
\hline 31 & 333 & 3 & 5 & 70 & 130 & 0.7 & strong & low & mixed & fir & clay/gravel & partial & large \\
\hline 32 & 344 & 5 & 9 & 50 & 110 & 0.8 & intermediate & intermediate & mixed & fir & clay/gravel & partial & large \\
\hline 33 & 355 & $3 / 8$ & 10 & 40 & 150 & 0.8 & intermediate & intermediate & mixed & fir & stones/clay/gravel & complete & medium \\
\hline 34 & 280 & 3 & 7 & 50 & 90 & na & strong & intermediate & deciduous & beech & clay/sand/gravel & partial & large \\
\hline 35 & 286 & 3 & 5 & 35 & 80 & na & strong & low & deciduous & beech & clay/sand/gravel & partial & medium \\
\hline 36 & 293 & 4 & 7 & 60 & 110 & 0.6 & weak & intermediate & deciduous & beech & clay & no & large \\
\hline 37 & 411 & 30 & 36 & 170 & 200 & 4.0 & weak & low & coniferous & fir & rock/gravel & partial & small \\
\hline 38 & 409 & 18 & 27 & 150 & 250 & 4.0 & weak & low & coniferous & fir & rock/gravel & complete & medium \\
\hline 39 & 407 & 4 & 7 & 50 & 60 & 0.5 & weak & intermediate & coniferous & fir & clay/gravel & complete & large \\
\hline 40 & 334 & 4 & 6 & 80 & na & 1.6 & intermediate & low & mixed & fir & gravel & complete & medium \\
\hline 41 & 325 & 3 & 4 & 55 & 100 & 1.0 & intermediate & low & mixed & fir & stones & no & medium \\
\hline
\end{tabular}




\section{DISCUSSION}

Cordulegaster bidentata is a rheobiontic and crenophilic species, breeding in springs and small mountain streams, often at their initial, headwater sections (eucrenal and hypocrenal zones). On larger watercourses it is found only exceptionally. It usually inhabits mid-forest watercourses, located in deciduous and mixed stands (Heidemann \& Seidenbusch 1993, Daraż 2009, Holuša 2009). Sometimes, it is found also in non-forest areas, for example in peat bogs (Heidemann \& Seidenbusch 1993) or high alpine grasslands (Holuša 2009), and in the Western Carpathians (Beskid Żywiecki Mountains) oviposition was observed even in a vast forest clearcut, located on a steep mountain slope (pers. obs.). Due to the acidification of the water, $C$. bidentata inhabits the catchments covered with coniferous stands less likely than located within deciduous forests (Tamm 2012, Kłonowska-Olejnik \& Buczyński 2014). In the studied area $C$. bidentata larvae commonly inhabited also streams flowing through stands with dominant fir, including almost pure fir forests. Boudot (2010) indicated, however, that some populations do not seem to be negatively affected by the presence of coniferous forests in the stream catchment, and this appears to be the case for the studied population from the Wielickie Foothills. It may be related to the chemistry of soils present in the region or the structure of the local forest communities, which, despite the significant deforestation of the area, still has a diversified and largely natural species composition, with a high proportion of deciduous and mixed stands in most forest patches.

C. bidentata larvae usually inhabit small streams characterised by considerable channel slopes, springs and associated seepage waters and wetlands (Heidemann \& Seidenbusch 1993, Liepelt 2005, Boudot 2010). In the stream, larvae choose deeper fragments (pools) in which the water current is slowed down (e.g. up- and downstream from logs, boulders, rocky steps etc.); often, though not always, these are partially shaded places (Liepelt 2005, Daraż 2009, Liebelt et al. 2011, Kłonowska-Olejnik \& Buczyński 2014). In this type of microhabitats, larvae were found also in the Wielickie Foothills - only in a few cases riffles with shallow, rapidly flowing water were occupied. The upper sections of streams in the studied area often carry little water, but it is known that the larvae of $C$. bidentata are resistant to water temperature fluctuations and drying out. They can survive periods of drought in moist material in the bottom cavities and under stones (Heidemann \& Seidenbusch 1993, Liebelt et al. 2011). In addition, larvae tend to bury themselves in the bottom sediments of the stream. For example, in the Wiśnickie Foothills, all larvae recorded by Kłonowska-Olejnik \& Buczyński (2014) were deeply buried and only after some time after the disturbance of the bottom sediment, they appeared on its surface. Instead, in the current study numerous larvae were found on the bottom surface, covered only with a thin layer of silt, forming a camouflage, which reduced their visibility on the stream bed. This is to a large extent due to a different research method - the kick sampling in the Wiśnickie Foothills, versus scanning of the stream bottom in the current study. But this does not explain why no larvae were present on the bottom surface in the stream sampled by Kłonowska-Olejnik \& Buczyński (2014). As such differentiation of larval behaviour in similar habitats of neighbouring regions of the Carpathian Foothills seems unlikely, current observations prove that a number of C. bidentata larvae are not usually buried deep in sediments, but remain on the bottom surface and, despite good camouflage - are available for visual detection. It can be assumed that covering with a layer of silt allows the larvae to hunt more effectively, although it cannot be excluded that it also protects against detection by a potential predator. However, it is probably more important to hide from a potential prey, which is indicated by observations of the larvae released in the 
places of their capture - only in one case out of 49, the larva immediately after the release buried itself in the silt covering the bottom. In other cases, the released larvae slowly went into deeper parts of the pool or stayed immobile, without attempting to bury themselves in sediments.

Kłonowska-Olejnik \& Buczyński (2014), based on the site of $C$. bidentata discovered in the Wiśnickie Foothills, considered whether the range of this dragonfly reaches the valley of the Vistula river, or whether north of the Beskidy mountain ranges the species occurs only in few dispersed sites. The distribution of $C$. bidentata in the western part of the Wielickie Foothills, recognized during current study, confirmed that this species reaches (in the north) the line of Vistula, occurring in the foothills of Western Carpathians up to its orographic edge, including the lowest and northernmost parts of these mountain range. What is more, the results also indicate that the distribution of this dragonfly is basically uninterrupted between the Vistula valley and the previously known northern limit of range, running along the northern edge of the Beskidy Mountains (Bernard et al. 2009, Fig. 2). New data shift this limit in the Western Carpathians by nearly $20 \mathrm{~km}$ to the north, and suggest that the species is much more common in the foothill part of the region that it was previously thought. However, the full recognition of the northern limit of species range in the Western Carpathians requires further studies in other parts of the region. It should also be noted that it is not entirely certain that the Vistula river valley is the actual limit of $C$. bidentata range. To verify this, the search for larvae in potentially relevant stream habitats should include forested hills adjacent to the Vistula valley from the north, already outside the Carpathian mountain range (Solon et al. 2018).

C. bidentata larvae in the Wielickie Foothills were distributed in spatially separate patches of forests covering higher hills, comprising streams of natural character. In the fragmented landscape, this species used patches of appropriate breeding habitats, separated by areas not suitable for colonization - deforested and turned into arable crops or built-up areas. Although no specific data are available for $C$. bidentata, adult dragonflies are classified as organisms with high dispersive abilities (Conrad et al. 1999). For this reason, for such a large flying insect, occupied sites in the Wielickie Foothills, separated from the nearest neighbour by no more than $3.7 \mathrm{~km}$ (and on average only about $1 \mathrm{~km}$ ), should not be regarded as isolated in a population sense, despite the discontinuity of habitats. It can be assumed that originally, before this area was strongly deforested, the occurrence of $C$. bidentata was more continuous here, and the spatial isolation of sites was only slight. Therefore, the preservation of the natural, hydrotechnically unmodified character of clean, mid-forest streams in the Carpathian Foothills, along with the remaining at least 75-100-ha patches of diversified forests, is the basic condition securing the existence of this near-threatened dragonfly species on the edge of its range.

Rapid visual searching of streams using binoculars for scanning of their bottom, as a typically qualitative method, has proved to be very efficient for recognizing the occurrence of $C$. bidentata larvae in large areas. Despite the difficult conditions of fieldwork conducted in narrow stream valleys with steep slopes, a single observer during over a dozen of several-hour field visits was able to examine 47 streams, searching each time about $1.5 \mathrm{~km}$ of the watercourse. Certainly not all larvae were found on the examined stream sections, however, to recognize the general pattern of occurrence in a given area, the method used was absolutely sufficient. The use of more accurate methods, which enable quantitative analysis (e.g. kick sampling, sieving or sweep-net sampling; Stark et al. 2001) would undoubtedly increase the detection rate. However, due to their high fieldwork intensity, these methods do not allow searching long sections of watercourses in a short time and are not suitable for large-scale survey of species distribution. Not without significance is the fact that the use of a method that did not require disturbance of the watercourse bottom secured the larval microhabitats from damage. And this, due to the small area of stream pools and high conservation status of the species, should have been avoided. The recommended, combined use of larvae, exuviae and adults searching (Tamm 2012, 2018) could also be efficient 
or even superior, but the use of this method is limited to the period when exuviae and adults can be recorded. Since the larvae are available for detection over a longer period (including late summer and autumn), the method used in this study is less limited in terms of the time of the season. A wider application of the rapid method of detecting the presence of larvae described in this paper would allow a more complete recognition of the actual range of $C$. bidentata in the Carpathians, which - as current results show - is still incomplete and requires further studies, especially in the Carpathian Foothills.

\section{ACKNOWLEDGEMENTS}

I would like to thank the anonymous reviewers for their constructive comments, improving early version of the manuscript.

\section{REFERENCES}

BERnARD R., BuCZyŃSKi P., TOŃCZYK G. \& WENDZONKA J. 2009. A distribution atlas of dragonflies (Odonata) in Poland. Bogucki Wydawnictwo Naukowe, Poznań, 256 pp.

BiS B. \& MiKULEC A. 2013. Przewodnik do oceny stanu ekologicznego rzek na podstawie makrobezkręgowców bentosowych. Biblioteka Monitoringu Środowiska, GIOŚ, Warszawa, 122 pp. Available at http://www.gios.gov.pl/images/dokumenty/pms/monitoring_wod/PRZEWODNIK_DO_OCENY_STANU_EKOL OGICZNEGO_RZEK_MAKROBENTOS_2013.pdf

BORKOWSKI A. 2012. Wažki (Odonata) byłego województwa jeleniogórskiego z uwagami do aktualnego stanu badań, zagrożeń oraz potrzeb ochrony. Przyroda Sudetów Zachodnich 2: 37-56.

Boudot J.-P. 2001. Les Cordulegaster du Paléarctique occidental: identification et repartition (Odonata, Anisoptera, Cordulegastridae). Martinia 17: 1-34.

BoudOT J-P. 2010. Cordulegaster bidentata. The IUCN Red List of Threatened Species 2010: e.T165498A6041602. https://dx.doi.org/10.2305/IUCN.UK.2010-1.RLTS.T165498A6041602.en (accessed 27 Jan 2020).

Boudot J.-P.\& HolUŠA O. 2015. Cordulegaster bidentata Selys, 1843. Pp. 212-213. In: BOUdOT J.-P. \& KALKMAN V. J. (eds), Atlas of the European dragonflies and damselflies. KNNV publishing, the Netherlands.

Conrad K. F., Willson K. H., Harvey I. F., Thomas C. J. \& Sherratt T. N. 1999. Dispersal characteristics of seven odonate species in an agricultural landscape. Ecography 22: 524-531.

DARAŻ B. 2009. Ważki (Odonata) Pogórza Przemyskiego i przyległych obszarów wzdłuż Sanu. Wiadomości Entomologiczne 28: 5-32.

GołĄв M., Potoczek M. \& Śniegula S. 2010. Nowe stanowiska Cordulegaster bidentata SÉlys, 1843 (Odonata: Cordulegastridae) w Beskidzie Wyspowym oraz w Bieszczadach. Wiadomości Entomologiczne 29: 205.

HeidemanN H. \& SEIDENBusch R. 1993. Die Libellenlarven Deutschlands und Frankreichs. Handbuch für Exuviensammler. Verlag Erna Bauer, Keltern.

HoluŠA O. 2009. New records of Cordulegaster bidentata and Somatochlora alpestris in the Ukrainian Carpathians (Odonata: Cordulegastridae, Corduliidae). Libellula 28: 191-201.

IUCN (International Union for Conservation of Nature) 2009. Cordulegaster bidentata. The IUCN Red List of Threatened Species. Version 2019-3. http://www.iucnredlist.org (accessed 8 Feb 2020).

Kalkman V.J., Boudot J.-P., Bernard R., Conze K.-J., De KniJf G., Dyatlova E., Ferreira S., Jović M., Ott J., RiSERVATO E. \& SAHLÉN G. 2010. European Red List of Dragonflies. Publications Office of the European Union, Luxembourg, $30 \mathrm{pp}$.

KŁONOWSKA-OlEJNIK M. \& BUCZYŃSKi P. 2014. Dysjunktywna populacja Cordulegaster bidentata SÉLYS, 1843 (Odonata: Cordulegastridae) na Pogórzu Wiśnickim (Polska południowa). Wiadomości Entomologiczne 33: 5-14.

KONDRACKI J. 2013. Geografia regionalna Polski. PWN, Warszawa, 441 pp.

Liebelt R., LOHR M. \& Beinlich B. 2011 Zur Verbreitung der Gestreiften und der Zweigestreiften Quelljungfer (Cordulegaster bidentata und C. boltonii) im Kreis Höxter (Insecta, Odonata, Cordulegastridae). Beiträge zur Naturkunde zwischen Egge und Weser 22: 3-18.

LEIPELT K. G. 2005 . Behavioural differences in response to current: implications for the longitudinal distribution of stream odonates. Archiv Für Hydrobiologie 163: 81-100.

LimaNóWKa D. 2008. Zmienność klimatu Pogórza Wielickiego w latach 1978-2003 (na przykładzie stacji Dobczyce). Prace Geograficzne 119: 9-28.

Margielewski W., Święchowicz J., Starkel L., ŁajCZAK A. \& PietrZaK M. 2008. Współczesna ewolucja rzeźby Karpat fliszowych. Pp. 57-133. In: Starkel L., Kostrzewski A., Kotarba A. \& Krzemień K. (eds), Współczesne przemiany rzeźby Polski. Instytut Geografii i Gospodarki Przestrzennej UJ, Kraków, 400 pp.

PEŁeCH S. 2012. Charakterystyka warunków śniegowych do uprawiania narciarstwa na Pogórzu Wielickim. Prace Geograficzne 128: 17-27. 
PRÜFFER J. 1920. Materjały do fauny ważek południowo-zachodniej Polski. Sprawozdania Komisji Fizjograficznej PAU 53-54: 138-148.

Smolis A., Kadej M., Bena W., Malkiewicz A., Zając K., MańKowska-Jurek D. \& RąPaŁa R. 2012. Nowe dane o rozsiedleniu ważek (Insecta: Odonata) na Śląsku. Przyroda Sudetów 15: 57-66.

Solon J., BorzyszKowski J., BidŁASIK M., Richling A., BAdORA K., BAlon J., BrzeziŃSKA-WóJCiK T., CHABUdZIŃSKi Ł., DOBROWOlSKi R., GRZEGORCZYK I., JODŁOWSKi M., KistowSKi M., KOT R., KRĄŻ P., LECHNIO J., Macias A., Majchrowska A., Malinowska E., Migoń P., MYga-PiąteK U., Nita J., Papińska E., Rodzik J., STRZYŻ M., TERPIŁOWSKI S. \& ZIAJA W. 2018. Physico-geographical mesoregions of Poland - verification and adjustment of boundaries on the basis of contemporary spatial data. Geographia Polonica 91(2): 143-170.

Stark J. D., Boothroyd I. K. G., Harding J. S., MaXted J. R. \& Scarsbrook M. R. 2001. Protocols for sampling macroinvertebrates in wadeable streams. New Zealand Macroinvertebrate Working Group Report No. 1. Wellington, New Zealand, 57 pp.

TAMM J. 2012 Cordulegaster bidentata in Hessen mit besonderer Berücksichtigung ihrer Bindung an den geologischen Untergrund (Odonata: Cordulegastridae). Libellula 31: 131-154.

TAMM J. 2018. Untersuchungen an Larven und Exuvien der Cordulegaster bidentata an einem Bach im Kaufunger Wald und ihre ökologischen und methodischen Konsequenzen (Odonata: Cordulegastridae). Libellula 37: 161-180.

\section{STRESZCZENIE}

\section{[Ważka Cordulegaster bidentata Selys, 1843 w pofragmentowanym krajobrazie Pogórza Wielickiego: rewizja północnej granicy zasięgu gatunku w Karpatach Zachodnich]}

Cordulegaster bidentata Selys, 1843 należy do ważek wyspecjalizowanych siedliskowo, o zasięgu ograniczonym do obszarów górskich. Z uwagi na słabo rozpoznany przebieg północnej granicy zasięgu gatunku w Karpatach Zachodnich, w latach 2018-2019 podjęto próbę jego oceny na obszarze peryferycznie położonej, zachodniej części Pogórza Wielickiego, leżącego pomiędzy pasmami górskimi Beskidów (na południu) a doliną rzeki Wisły (na północy). Celem pracy było ponadto sprawdzenie czy $C$. bidentata zasiedla obszary Pogórza Karpackiego o pofragmentowanej strukturze krajobrazu leśnego, z wyspami różnej wielkości płatów lasów, rozdzielonymi terenami rolnymi i zabudowanymi.

Badano występowanie larw na początkowych, źródliskowych odcinkach bezrybnych, śródleśnych potoków. Ogółem zbadano 53 odcinki o łącznej długości 21,5 km, zlokalizowane na 47 potokach przepływających przez wszystkie większe kompleksy leśne leżące na terenie badań. Do wykrywania larw wykorzystano szybką, jakościową metodę, polegającą na wypatrywaniu larw $C$. bidentata w preferowanych przez ten gatunek mikrosiedliskach przegłębieniach koryt potoków. Dno przegłębień skanowano wizualnie, przy użyciu lornetki, w poszukiwaniu larw przebywających na jego powierzchni.

Obecność larw $C$. bidentata potwierdzono na 17 odcinkach 16 potoków (odpowiednio 32\% i 34\% spośród wszystkich zbadanych). Łącznie na 41 stanowiskach odnaleziono 49 larw mierzących $>30$ mm długości, w tym 23 samce i 26 samic. Ponadto, na tych samych odcinkach potoków odnaleziono 15 larw Cordulegaster sp., mierzących 18-29 mm, których z uwagi na małe rozmiary nie identyfikowano do poziomu gatunkowego. Larwy stwierdzano w niemal całej rozciągłości geograficznej terenu badań, od najbardziej południowych aż po najdalej na północ wysunięte kompleksy leśne, położone na krawędzi progu pogórza opadającego do doliny rzeki Wisły. W pofragmentowanym krajobrazie larwy $C$. bidentata notowano w płatach lasu o wielkości 75-1280 ha. Najbliższe stanowiska położone na sąsiednich zasiedlonych potokach oddalone były o nie więcej niż $3,7 \mathrm{~km}$, a przeciętnie tylko o nieco ponad $1 \mathrm{~km}$. Rozmieszczenie odnalezionych stanowisk potwierdziło, że gatunek ten osiąga linię Wisły, występując na Pogórzu Zachodniobeskidzkim aż do jego orograficznej krawędzi. Wskazuje jednocześnie, że rozmieszczenie $C$. bidentata - przynajmniej na badanym odcinku Karpat - jest w zasadzie nieprzerwane pomiędzy północnym skrajem pasm górskich Beskidów a doliną Wisły. Nowe dane przesuwają północną granicę zasięgu C. bidentata w Karpatach Zachodnich o blisko $20 \mathrm{~km}$ i sugerują, że ten gatunek jest na pogórzach znacznie częstszy niż dotychczas uważano. 
Zastosowana w badaniach szybka, typowo jakościowa metoda okazała się bardzo efektywna i użyteczna do rozpoznawania występowania larw $C$. bidentata na dużych obszarach, przy relatywnie niewielkim nakładzie pracy. Szersze jej zastosowanie pozwoliłoby na pełniejsze rozpoznanie rozmieszczenia $C$. bidentata na obszarze pogórzy karpackich, które nadal jest niewystarczające.

Accepted: 30 Oct 2020 
Appendix 1. Sections of streams investigated for the presence of Cordulegaster bidentata larvae in the Wielickie Foothills.

\begin{tabular}{|c|c|c|c|c|c|c|c|}
\hline $\begin{array}{l}\text { Section } \\
\text { ID }\end{array}$ & $\begin{array}{l}\text { Stream } \\
\text { ID }\end{array}$ & $X(o E)$ & $\mathrm{Y}(\mathrm{oN})$ & Altitude & $\begin{array}{l}\text { Section } \\
\text { length }\end{array}$ & Date of visit & $\begin{array}{c}\text { Forest patch } \\
\text { area [ha] }\end{array}$ \\
\hline 1 & 1 & 19.653370 & 49.875111 & 305 & 198 & 5 Aug 2018 & 75 \\
\hline 2 & 1 & 19.649643 & 49.875353 & 314 & 122 & 5 Aug 2018 & 75 \\
\hline 3 & 2 & 19.649694 & 49.877043 & 336 & 479 & 5 Aug 2018 & 75 \\
\hline 4 & 3 & 19.645445 & 49.879412 & 332 & 453 & 5 Aug 2018 & 75 \\
\hline 5 & 4 & 19.645721 & 49.881304 & 333 & 323 & 5 Aug 2018 & 75 \\
\hline 6 & 5 & 19.648782 & 49.882420 & 324 & 639 & 5 Aug 2018 & 75 \\
\hline 7 & 6 & 19.601788 & 49.891755 & 358 & 565 & 18 Aug 2018, 21 Sep 2019 & 520 \\
\hline 8 & 7 & 19.554576 & 49.886636 & 314 & 336 & 18 Aug 2018 & 306 \\
\hline 9 & 8 & 19.538224 & 49.956478 & 351 & 1137 & 23 Jun 2019 & 230 \\
\hline 10 & 9 & 19.542229 & 49.952779 & 326 & 166 & 23 Jun 2019 & 230 \\
\hline 11 & 10 & 19.550422 & 49.952033 & 325 & 320 & 23 Jun 2019 & 230 \\
\hline 12 & 11 & 19.557198 & 49.951779 & 292 & 309 & 23 Jun 2019 & 230 \\
\hline 13 & 8 & 19.553634 & 49.954774 & 284 & 83 & 23 Jun 2019 & 230 \\
\hline 14 & 12 & 19.624424 & 49.919547 & 335 & 578 & 6 Jul 2019 & 1280 \\
\hline 15 & 13 & 19.621067 & 49.915716 & 363 & 327 & 6 Jul 2019 & 1280 \\
\hline 16 & 15 & 19.601441 & 49.886200 & 331 & 854 & 3 Aug 2019 & 520 \\
\hline 17 & 16 & 19.608966 & 49.888505 & 367 & 956 & 4 Aug 2019 & 520 \\
\hline 18 & 15 & 19.594295 & 49.893534 & 392 & 398 & 11 Aug 2019 & 520 \\
\hline 19 & 17 & 19.589232 & 49.891641 & 381 & 154 & 11 Aug 2019 & 520 \\
\hline 20 & 18 & 19.536336 & 49.961893 & 311 & 1068 & 16 Aug 2019 & 230 \\
\hline 21 & 19 & 19.538723 & 49.961396 & 310 & 113 & 16 Aug 2019 & 230 \\
\hline 22 & 18 & 19.553002 & 49.970703 & 243 & 204 & 16 Aug 2019 & 230 \\
\hline 23 & 20 & 19.544545 & 49.967187 & 259 & 272 & 16 Aug 2019 & 230 \\
\hline 24 & 21 & 19.523725 & 49.967479 & 294 & 388 & 16 Aug 2019 & 291 \\
\hline 25 & 22 & 19.608778 & 49.966686 & 239 & 225 & 24 Aug 2019 & 103 \\
\hline 26 & 23 & 19.579184 & 49.968486 & 251 & 413 & 24 Aug 2019 & 103 \\
\hline 27 & 21 & 19.525238 & 49.973628 & 270 & 512 & 24 Aug 2019 & 291 \\
\hline 28 & 24 & 19.520712 & 49.966408 & 315 & 193 & 24 Aug 2019 & 291 \\
\hline 29 & 25 & 19.519402 & 49.964845 & 324 & 247 & 24 Aug 2019 & 291 \\
\hline 30 & 26 & 19.522199 & 49.957890 & 307 & 159 & 24 Aug 2019 & 291 \\
\hline 31 & 26 & 19.524985 & 49.959981 & 338 & 210 & 24 Aug 2019 & 291 \\
\hline 32 & 27 & 19.581548 & 49.918854 & 380 & 199 & 25 Aug 2019 & 1280 \\
\hline 33 & 28 & 19.570420 & 49.918463 & 338 & 127 & 25 Aug 2019 & 1280 \\
\hline 34 & 30 & 19.562728 & 49.915833 & 384 & 612 & 25 Aug 2019 & 1280 \\
\hline 35 & 31 & 19.478991 & 49.976989 & 302 & 510 & 31 Aug 2019 & 155 \\
\hline 36 & 32 & 19.475338 & 49.980757 & 295 & 364 & 31 Aug 2019 & 155 \\
\hline 37 & 33 & 19.468772 & 49.972563 & 289 & 446 & 31 Aug 2019 & 155 \\
\hline 38 & 34 & 19.476929 & 49.973639 & 293 & 548 & 31 Aug 2019 & 155 \\
\hline 39 & 35 & 19.648683 & 49.932921 & 310 & 178 & 28 Sep 2019 & 1280 \\
\hline 40 & 36 & 19.650173 & 49.928162 & 317 & 998 & 28 Sep 2019 & 1280 \\
\hline 41 & 29 & 19.572127 & 49.917127 & 351 & 229 & 25 Aug 2019 & 1280 \\
\hline 42 & 37 & 19.659464 & 49.925963 & 298 & 398 & 28 Sep 2019 & 135 \\
\hline 43 & 38 & 19.672077 & 49.910509 & 321 & 447 & 28 Sep 2019 & 145 \\
\hline 44 & 39 & 19.671523 & 49.912442 & 336 & 190 & 28 Sep 2019 & 145 \\
\hline 45 & 40 & 19.658819 & 49.859035 & 421 & 1009 & 29 Sep 2019 & 714 \\
\hline 46 & 41 & 19.655434 & 49.858933 & 428 & 815 & 29 Sep 2019 & 714 \\
\hline 47 & 43 & 19.656436 & 49.857026 & 454 & 222 & 29 Sep 2019 & 714 \\
\hline 48 & 44 & 19.647246 & 49.858659 & 418 & 355 & 29 Sep 2019 & 714 \\
\hline 49 & 45 & 19.624116 & 49.925010 & 383 & 411 & 12 Oct 2019 & 1280 \\
\hline 50 & 46 & 19.627913 & 49.925618 & 366 & 418 & 12 Oct 2019 & 1280 \\
\hline 51 & 47 & 19.632477 & 49.927834 & 344 & 163 & 12 Oct 2019 & 1280 \\
\hline 52 & 13 & 19.628497 & 49.916508 & 329 & 252 & 6 Jul 2019 & 1280 \\
\hline 53 & 14 & 19.623502 & 49.920816 & 341 & 176 & 6 Jul 2019 & 1280 \\
\hline
\end{tabular}

